J. clin. Path. (1952), 5, 10.

\title{
THE INFLUENCE OF AGE UPON SERUM IRON IN NORMAL SUBJECTS
}

\author{
BY \\ ROBERT PIRRIE \\ From the Muirhead Department of Medicine, the University and Royal \\ Infirmary, Glasgow
}

(RECEIVED FOR PUBLICATION MAY 1, 1951)

This investigation was carried out in order to explore the possibility of a correlation between the process of ageing and the concentration of iron in the serum. It also provides additional information on the reliability of the potassium ferricyanide method for the determination of serum iron.

Vahlquist (1941) studied the influence of age upon serum iron concentration during the first 15 years of life. Within 24 hours of birth, serum iron falls from its neonatal value of $160 \mu \mathrm{g}$. \% to a level of $50 \mu \mathrm{g}$. \%. A secondary rise to 125 $\mu \mathrm{g}$. \% during the next two weeks is succeeded by a gradual fall so that the average value in the age group 6 months to 2 years is $60 \mu \mathrm{g}$. \%. After the second year the concentration of iron in the serum increases progressively to an average of $100 \mu \mathrm{g} . \%$ at 7 years, $110 \mu \mathrm{g}$. \% at 11 years, and $120 \mu \mathrm{g}$. \% at 15 years. Eckerström $(1944 \mathrm{a}, \mathrm{b})$ determined serum iron in 100 subjects over 70 years of age and found that not only was the sex difference in serum iron still apparent at these ages, but also that serum iron was significantly lower than in healthy subjects under 30 years of age.

\section{Material and Methods}

The material was composed mainly of blood donors, namely healthy individuals between the ages of 17 and 65 years of age, who gave no history of recent illness, whose physical condition was good, and whose haemoglobin was $85 \%$ or more, as estimated by the copper sulphate method of Philips, Van Slyke, Dole, Emerson, Hamilton, and Archibald (1945). The age groups 10 to 17 years and 65 to 80 years were composed respectively of children with minor injuries and of adult volunteers whose health standard conformed to the above criteria. Females who were menstruating were rejected. All specimens were withdrawn in the afternoon. In the case of blood donors, serum iron was determined on samples removed immediately after withdrawal of $540 \mathrm{ml}$. of blood. This procedure was desirable, since it minimized interference with the regime of the transfusion service, but was adopted only after it was shown that the iron content of the serum was not influenced significantly by the immediately preceding donation of blood. This observation agrees with that of Heilmeyer and Plötner (1937), who noted that the withdrawal of 500 to $800 \mathrm{ml}$. of blood from normal persons did not reduce serum iron until at least six hours later. Likewise, Br $\phi$ chner-Mortensen (1943), who studied two cases of acute gastro-intestinal haemorrhage from the onset, obtained normal values for serum iron during the first 24 hours. 
Serum iron was determined by the potassium ferricyanide method of Fitzpatrick and Howells (1949) by whom it has been described in detail. Throughout the estimations every precaution was taken to ensure freedom of contamination with iron. The final colour was measured by a Spekker absorptiometer, for which a calibration curve was constructed by reference to serial dilutions of a standard solution of ferrous ammonium sulphate.

\section{Results}

As a measure of the experimental error involved, the iron content of aliquot portions of the same serum was estimated in duplicate in ten different individuals chosen at random (Table I). The difference in the mean values of these deter-

TABLE I

DUPlicate Estimations of SERUM IRON

\begin{tabular}{|c|c|c|c|}
\hline \multirow{2}{*}{ Serum } & \multicolumn{2}{|c|}{ Iron Content ( $\mu \mathrm{g} . \%$ ) } & \multirow{2}{*}{ Difference } \\
\hline & 1 & 2 & \\
\hline 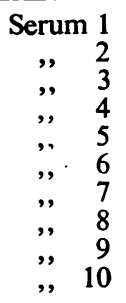 & $\begin{array}{c}170 \\
112 \\
93 \\
113 \\
60 \\
70 \\
100 \\
111 \\
119 \\
140\end{array}$ & $\begin{array}{r}165 \\
120 \\
81 \\
120 \\
60 \\
80 \\
93 \\
119 \\
119 \\
133\end{array}$ & $\begin{array}{r}-5 \\
+8 \\
-12 \\
+7 \\
0 \\
+10 \\
-7 \\
+8 \\
0 \\
-7\end{array}$ \\
\hline
\end{tabular}

minations is only $0.2 \mu \mathrm{g}$. \%. The standard error of a single determination is $\pm 5.5 \mu \mathrm{g}$. \%, so that any single determination of serum iron can be considered liable to a maximum error of $\pm 11 \mu \mathrm{g}$. \%.

In order to establish that serum iron was not immediately influenced by the withdrawal of $540 \mathrm{ml}$. of blood, serum iron was determined in six males and six females immediately before and after blood donation. The means and the standard errors of the results are presented in Table II. There is no significant difference between serum iron values obtained before or after donation of blood in either sex.

TABLE II

Serum Iron Estimated Immediately Before aNd After Withidawal of 540 ML. OF BLOOD

\begin{tabular}{|c|c|c|c|c|c|c|c|}
\hline & & & & \multicolumn{2}{|c|}{$\underset{(\mu \mathrm{g} . \%)}{\text { Mean Values }}$} & \multirow{2}{*}{$\begin{array}{l}\text { Difference } \\
(\mu \mathrm{g} . \%)\end{array}$} & \multirow{2}{*}{$\begin{array}{l}\text { Standard Error } \\
\text { of Difference of } \\
\text { Means } \\
(\mu \mathrm{g} . \%)\end{array}$} \\
\hline & & & & Before & After & & \\
\hline $\begin{array}{l}\text { Males } \\
\text { Females }\end{array}$ & $\begin{array}{l}\ldots \\
\cdots\end{array}$ & $\begin{array}{l}\cdots \\
\cdots\end{array}$ & $\begin{array}{l}\ldots \\
\cdots\end{array}$ & $\begin{array}{l}94 \cdot 5 \\
87 \cdot 3\end{array}$ & $\begin{array}{l}98 \cdot 8 \\
83 \cdot 8\end{array}$ & $\begin{array}{l}4 \cdot 3 \\
3 \cdot 5\end{array}$ & $\begin{array}{l} \pm 3.9 \\
\pm 3.9\end{array}$ \\
\hline
\end{tabular}


The values obtained for serum iron in the various age groups of normal individuals are summarized in Table III and compared with those obtained by previous workers in Table IV. The mean values for serum iron and the standard errors are $103 \pm 3.10 \mu \mathrm{g}$. \% in men and $91 \pm 2.83 \mu \mathrm{g}$. \% in women. These results are lower

TABLE III

Mean Values for Serum Iron in Normal Subjects

\begin{tabular}{c|c|c|c|c|c|c}
\hline & \multicolumn{3}{|c|}{ Males } & \multicolumn{3}{|c}{ Females } \\
\cline { 2 - 6 } $\begin{array}{c}\text { Age } \\
\text { (Years) }\end{array}$ & $\begin{array}{c}\text { Number } \\
\text { of } \\
\text { Subjects }\end{array}$ & $\begin{array}{c}\text { Range } \\
(\mu \mathrm{g} . \%)\end{array}$ & $\begin{array}{c}\text { Mean } \\
(\mu \mathrm{g} . \%)\end{array}$ & $\begin{array}{c}\text { Number } \\
\text { of } \\
\text { Subjects }\end{array}$ & $\begin{array}{c}\text { Range } \\
(\mu \mathrm{g} . \%\end{array}$ & $\begin{array}{c}\text { Mean } \\
(\mu \mathrm{g} . \%)\end{array}$ \\
\hline $10-15$ & 4 & $65-120$ & 97 & 5 & $66-112$ & 92 \\
$16-20$ & 5 & $112-148$ & 129 & 7 & $86-137$ & 116 \\
$21-30$ & 18 & $92-188$ & 132 & 15 & $74-143$ & 116 \\
$31-40$ & 26 & $76-170$ & 115 & 12 & $56-142$ & 100 \\
$41-50$ & 19 & $74-130$ & 96 & 19 & $45-137$ & 89 \\
$51-60$ & 16 & $55-130$ & 90 & 21 & $35-119$ & 76 \\
$61-70$ & 10 & $55-101$ & 84 & 12 & $45-111$ & 75 \\
$71-80$ & 10 & $55-111$ & 75 & 7 & $45-95$ & 66 \\
$10-80$ & 108 & $55-188$ & 103 & 98 & $35-143$ & 91 \\
\hline
\end{tabular}

TABLE IV

Summary of Published Data on Serum Iron in Normal Subjects

\begin{tabular}{|c|c|c|c|c|c|c|c|}
\hline \multirow{2}{*}{ Investigator } & \multirow{2}{*}{ Date } & \multicolumn{3}{|c|}{ Males } & \multicolumn{3}{|c|}{ Females } \\
\hline & & No. & $\left|\begin{array}{c}\text { Mean } \\
(\mu \mathrm{g} . \%)\end{array}\right|$ & $\begin{array}{c}\text { Range } \\
(\mu \mathrm{g} . \%)\end{array}$ & No. & $\begin{array}{c}\text { Mean } \\
(\mu \mathrm{g} . \%)\end{array}$ & $\begin{array}{l}\text { Range } \\
(\mu \text { g. \% })\end{array}$ \\
\hline 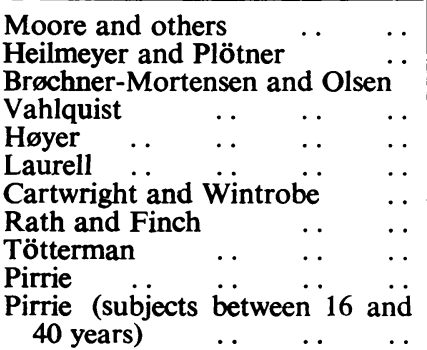 & $\begin{array}{l}1937 \\
1937 \\
1940 \\
1941 \\
1944 \\
1947 \\
1949 \\
1949 \\
1949 \\
1951 \\
1951\end{array}$ & $\begin{array}{r}15 \\
25 \\
20 \\
50 \\
50 \\
61 \\
15 \\
15 \\
67 \\
108 \\
49\end{array}$ & $\begin{array}{l}121 \\
126 \\
132 \\
142 \\
131 \\
124 \\
127 \\
106 \\
140 \\
103 \\
126\end{array}$ & $\begin{array}{l}94-174 \\
81-162 \\
90-194 \\
68-263 \\
63-189 \\
70-214 \\
79-196 \\
87-147 \\
88-276 \\
55-188 \\
65-188\end{array}$ & $\begin{array}{l}15 \\
25 \\
20 \\
50 \\
50 \\
39 \\
15 \\
15 \\
66 \\
98 \\
34\end{array}$ & $\begin{array}{r}97 \\
89 \\
127 \\
123 \\
114 \\
108 \\
123 \\
94 \\
121 \\
91 \\
111\end{array}$ & $\begin{array}{r}58-142 \\
64-128 \\
79-191 \\
53-210 \\
69-197 \\
57-196 \\
101-164 \\
72-130 \\
70-202 \\
35-143 \\
56-142\end{array}$ \\
\hline
\end{tabular}

than those previously reported. It is considered, however, that the cause of this discrepancy is the introduction of older age groups in the present series so that its average age is considerably higher than that of previous ones. When all individuals in the age groups 16 to 40 years are selected so as to provide material comparable to that used in previous investigations, mean values of $126 \mu \mathrm{g} . \%$ in 49 males and $111 \mu \mathrm{g} . \%$ in 34 females are obtained. These figures are in excellent agreement with those already published. 
The difference between the sexes in this series is $12 \pm 4.2 \mu \mathrm{g} . \%$ and is statistically significant. This difference is of the usual magnitude (Table IV). At puberty serum iron increases with age in both sexes, but the rise is greater in males and in this way the sex difference arises. Sex differentiation is maximal during the reproductive period of life and there is no tendency for serum iron to increase after the menopause.

The mean values for serum iron in the various age groups are presented in pictorial form in Fig. 1. Apart from the initial rise between puberty and the age group 20 to 30 years, there is a progressive and statistically highly significant fall in iron concentration in the serum with progressive increase in age. The rate of fall is approximately the same in both sexes.

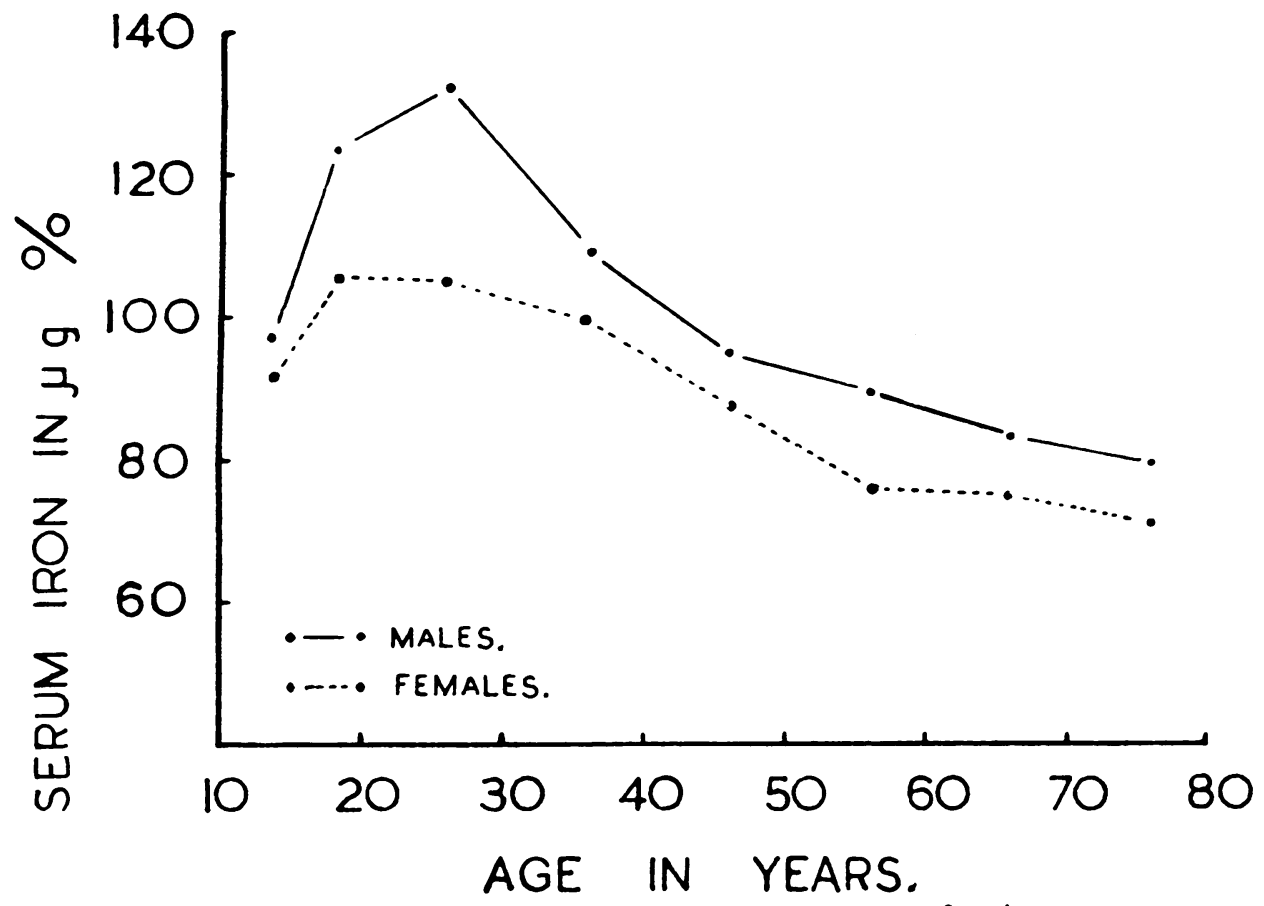

FIG. 1.-The relationship of serum iron to the process of ageing.

\section{Discussion}

The use of blood donors as normal material in an investigation of this kind is justified provided the usual precautions of routine examination and adequate interval between donations are observed. Under these circumstances, the possibility of cumulative iron deficiency is negligible. Hynes (1949) estimates that the usual donation of $450 \mathrm{ml}$. of blood contains $240 \mathrm{mg}$. and $220 \mathrm{mg}$. of iron in men and women respectively. Under normal conditions this amount of iron would be replaced by absorption of dietary iron within 60 days in men and 73 days in women. Hynes concludes, therefore, that iron deficiency would not occur, even in normal women, unless blood were donated more than five times per year. The minimum period between donations by subjects included in this series is six months. 
Vahlquist's contention (Vahlquist, 1941) that the difference in serum iron between sexes is due to an endocrinal factor and not to iron loss incurred by menstruation is supported by the present study, for not only does the sex difference arise from a proportionally greater increase in serum iron in males at puberty, but also reaches its maximum during the reproductive period of life, i.e. the period during which the activity of endocrinal factors is also at its maximum. During the same period, of course, the demand upon the iron reserves of women is also at its greatest, but cannot be the sole explanation of the maximum difference occurring at this time since there is no corresponding decrease in serum iron.

Little can be said at this stage about the progressive decrease in serum iron with the process of ageing, except to record it as a manifestation of the process. Iron may be less efficiently absorbed by older people, although it is interesting to note in this connexion that Eckerström (1944a) could find no correlation between achlorhydria and low serum iron in his series of aged subjects. Perhaps the general decrease in metabolic activity associated with ageing may be the explanation, in that the demand for the iron containing respiratory enzymes will be correspondingly diminished.

A study of the iron-combining power of the plasma would throw light on this problem. If decreased demand for iron were indeed the explanation of this hypoferraemia of the aged, then a corresponding diminution in plasma-combining power would be expected. On the other hand, if the low serum iron is a manifestation of iron deficiency, more potential than real since haemoglobin values are within normal limits, then the necessity of more efficient absorption and transportation of iron would be reflected by an increase in iron-combining power in the plasma. Laurell (1947) failed to establish a relationship between iron-combining power and ageing in his series of normal subjects, the majority of whom, however, fell between the ages of 15 and 40 years.

Values obtained for serum iron in normal subjects by various workers show a remarkable consistency despite the multitude of techniques employed. The results of this investigation show that the potassium ferricyanide method of Fitzpatrick and Howells (1949) is equally consistent. Its relative simplicity and the stability of the coloured complex make the method additionally attractive, especially when large numbers of determinations have to be carried out.

\section{Summary}

Mean values of $103 \pm 3.10 \mu \mathrm{g} . \%$ in males and $91 \pm 2.83 \mu \mathrm{g} . \%$ in females were established for serum iron in a series of 108 males and 98 females of ages varying from 10 to 80 years. The observed sex difference of $12 \pm 4.20 \mu \mathrm{g}$. \% was maximal during the reproductive period of life.

A progressive and highly significant decrease in serum iron with increasing age was noted and a tentative explanation offered.

The potassium ferricyanide method is a reliable method for the estimation of serum iron.

During this investigation the author held the Faulds Research Fellowship of Glasgow University, and part of the expenses incurred was provided by the Rankin Fund.

I have pleasure in recording my indebtedness to Professor L. J. Davis for his helpful advice, to Dr. J. Wallace for facilitating access to blood donors, and to Dr. R. A. Robb for his help in statistical methods. 


\section{REFERENCES}

Brøchner-Mortensen, K. (1943). Acta med. scand., 113, 345.

and Olsen, C. (1940). Nord. Med., 8, 2502.

Cartwright, G. E., and Wintrobe, M. M. (1949). J. clin. Invest., 28, 86.

Eckerström, S. (1944a). Nord. Med., 21, 276.

(1944b). Ibid., 24, 1843.

Fitzpatrick, J., and Howells, K. W. (1949). Journal of Clinical Pathology, 2, 290.

Heilmeyer, L., and Plötner, K. (1937). Das Serumeisen und die Eisenmangelkrankheit. Jena.

Høyer, K. (1944). Acta med. scand., 119, 562.

Hynes, M. (1949). Journal of Clinical Pathology, $2,99$.

Laurell, C. B. (1947). Acta physiol. scand., 14, Suppl. 46.

Moore, C. V., Arrowsmith, W. R., Quilligan, J. J., and Read, J. T. (1937). J. clin. Invest., $16,613$.

Philips, R. A., Van Slyke, D. D., Dole, V. P., Emerson, K., Hamilton, P. B., and Archibald, R. M. (1945). Copper Sulphate Method for Measuring Specific Gravities of Whole Blood and Plasma. New York.

Rath, C. E., and Finch, C. A. (1949). J. clin. Invest., 28, 79.

Tötterman, L. E. (1949). Acta med. scand., 134, Suppl. 230.

Vahlquist, B. (1941). Acta paediatr., Stockh., 28, Suppl. 5, 1. 